\title{
A hybrid of QFD and AHP-TOPSIS for Durg dumping waste projects
}

\author{
Rituraj Chandrakar $^{a^{*}}$ and Shivam Limje ${ }^{b}$
}

${ }^{a}$ Assistant Professor, Department of Mechanical Engineering at CSIT, Durg, India

${ }^{b}$ Department of Mechanical Engineering at CSIT, Durg, India

\section{H R O N I C L E \\ A B S T R A C T}

Article history:

Received: November 5, 2017

Received in revised format: February 20,2017

Accepted: February 20, 2018

Available online:

February 20, 2018

Keywords:

Waste Management

$A H P$

$M C D M$

$Q F D$

\begin{abstract}
Generation of solid waste is the integral consequence of civilization and its management is standing as a big challenge in front of state government at present time. Municipal solid waste in Durg-Bhilai is littered with improper places due to lack of understanding about the scientific importance of garbage and its consequences. Our foremost concern is the selection of appropriate dumping area nearby Durg-Bhilai (C.G.) and for the selection of appropriate dumping area, a multi criteria decision making technique is used. This paper attempts to evaluate 4 dumping areas based on 5 criteria. Analytical hierarchy process (AHP) is used to determine the weighs for each criterion and quality function deployment (QFD) is also implemented. The results indicate that Potiyakala was the best dumping site nearby Durg-Bhilai area.
\end{abstract}

\section{Introduction}

High population growth rate, industrialization, urbanization and economic growth are some of the most important factors contributing to the increase in municipal solid waste generation. Consumerism speed has been found very high covering around more than $50 \%$ of the total population since the last decade due to higher economic growth, which has ultimately resulted in an increased solid waste generation. The population has literally increased from 8.2 to 12.3 million in Mumbai during the period of Ten years (1981-97) at the rate of 49\%. Similarly the population growth has been found to rise exponentially in other Indian cities; however, the growth rate may be varying. In India, due to urbanization, there is an enhancement of solid waste generation which was $27.8 \%$ in 2001 and is expected to reach $41 \%$ by the end of 2021. In certain Indian cities, Solid waste generation was $0.64 \mathrm{~kg}$ in Kanpur, $0.52 \mathrm{~kg}$ in Lucknow, $0.4 \mathrm{~kg}$ in Varanasi, $0.59 \mathrm{~kg}$ in Ahmedabad and $0.44 \mathrm{~kg}$ in Mumbai in the year 1995. At present total solid waste generated in India is around 42 million tons annually. Waste generation varies from $200-600 \mathrm{~kg} /$ capita/day and collection efficiency ranges from $50-90 \%$. The maximum part of the overall waste is disposed of by the methods of landfilling on different sites selected on the basis of

\footnotetext{
* Corresponding author.

E-mail address: shivamlimje007@gmail.com (S. Limje) 
certain criteria and different geographical aspects. Every urban, semi-urban, and rural area has a specific location where wastes are dumped but the technology of disposal varies.

In India, in most of the places, the disposal is executed unprofessionally. The dumping condition is pathetic at some places which need attention from municipal government officials. The inadequate dumping causes poor management of waste and leads to the generation of different disease, disturbance in the lifestyle of living beings, adverse effects to our environment and deterioration of non-living properties due to hazardous gases of waste.

Here the authors tried to study the strategy of their management and performed a comparative study to find out the best among them. In the past, different authors have analyzed the present conditions of their respective places of concern. They did comprehensive studies on different steps of waste management and most importantly on dumping areas like Joshi and Ahmed (2016) made an attempt to evaluate the major parameters of MSWM, and also performed a comprehensive review of municipal solid waste (MSW) generation, its characterization, collection, and treatment options and reported the current state of MSW management (MSWM) in Indian states and some of the important cities. Sahu (2007) in his paper elaborated the generation of municipality waste, its identification, and processing. The author majorly focused on the dumping area geography and land availability and did a calculation on municipality waste of different cities of India. The author further did a case study on it in Mind Space, Mumbai. Similarly, Sharholy et al. (2008) made an attempt to provide a comprehensive review of the characteristics, generation, collection $\&$ transportation, disposal and treatment technologies of MSW usually practiced in India. They tried to evaluate the current status of MSW and identify major problems associated with it. Rajput et al. (2009) compared the waste generation $\mathrm{kg} / \mathrm{capita} /$ day and found that 2 $\mathrm{kg}$ in USA, $1.89 \mathrm{~kg}$ in Australia, $1.8 \mathrm{~kg}$ in Canada, $1.83 \mathrm{~kg}$ in Ireland, $1.1 \mathrm{~kg}$ in Belgium and Switzerland, $0.99 \mathrm{~kg}$ in Spain, $0.96 \mathrm{~kg}$ in Italy, $0.85 \mathrm{~kg}$ in Mexico and Greece during 1992 as per report and expected to be increased at least $25 \%$ by 2005 due to population and economic revolution. Agarwal et al. (2005) investigated and analyzed the MSW system in Delhi by focusing on recyclists which helped them evaluate the market mechanisms and details of the recycle trade in Delhi. Siddiqui et al. (2013) give details on waste collection scheme, present status of solid waste management and sanitary landfill in Mysore city. Similarly, solid waste generation in several developing countries and cities has been found in South East Asia region. Some important data can be mentioned such as $1.2 \mathrm{~kg}$ in Changging (1997), $0.6 \mathrm{~kg}$ in Shanghai (1993), $0.88 \mathrm{~kg}$ in Beijing (1991), $1.17 \mathrm{~kg}$ in Hong Kong residential cities and $3.9 \mathrm{~kg}$ commercial (1994), $1.5 \mathrm{~kg}$ in Tokyo, $2.7 \mathrm{~kg}$ in Osaka, Japan (1993), $0.66 \mathrm{~kg}$ in Jakarta, Indonesia (1993), $1.29 \mathrm{~kg}$ in Kuala Lumpur, Malaysia (1989), $0.53 \mathrm{~kg}$ in Metro Manila Philippines (1995), $0.5 \mathrm{~kg}$ in Khulana, Chittagong, Dhaka, $0.4 \mathrm{~kg}$ Sylhat, Bangladesh (1991). Bundela et al. (2010) considered that agricultural utilization of MSWC was the most cost-effective MSW option over traditional means like landfilling or incineration as it enables recycling of some potential plant nutrients but this can also lead to an environmental threat due to toxic pollutants and pathogens contained in it. They demonstrated the effects of MSWC amendment on soil microbial biomass.

Guria and Tiwari (2010) investigated and analyzed the recycling of the municipal solid waste in the Bilaspur city in Chhattisgarh. The authors made a complete study on municipal solid waste generation, its collection, transportation treatment technologies involved etc. Agarwal and Gupta (2011) explained the global significance of Hazardous Waste Management. Their work incorporates past and present scenario of waste treatment and disposal facility like Treatment, Storage and Disposal Facility (TSDF) for management of wastes generated from industries, regarding acts and regulation of the Government. Authors also worked on the Hazardous Waste Management Strategy, which includes- Identification of Hazardous Waste Generation, Data Collection, Waste Characterization, and Quantification of Hazardous Wastes, identification of Sites for Disposal, Conducting EIA and Implementing TSDF Program. They did the Waste Characterization, Quantification of Hazardous Wastes, identification of Sites for Disposal, Conducting EIA, Implementation of TSDF, Disaster Management, and Emergency Preparedness. Kaushal et al. (2012) analyzed the changing trend in the MSW quantities and characteristics in 
major urban agglomerations in India over the last four decades. They critically reviewed the present practices of estimating and forecasting MSW and highlight its limitations and changing needs of waste management technologies so that urban local bodies responsible for MSW management will prepare their plans efficiently. Lanjewar et al. (2014) mainly concentrated on municipal government's responsibility for implementing municipal solid waste management programs and facilities. Authors elaborated Integrated Solid Waste Management (ISWM). They concluded that solid waste management involves an interplay of six functional elements, namely generation of waste, storage, collection, transfer and transport, processing and recovery, and disposal. Raipur may still be lower in ranks in terms of per capita waste generation. The scenario can be changed only if the attitude of the people towards solid waste management changes. Muttamara et al. (1996) concluded that environmental pollution can be minimized by converting open dumping into a sanitary landfill with proper environmental protection measures \& If possible, the government should adopt waste-to-energy treatment system.

Multi criteria decision making (MCDM) approaches have been widely used by authors in the past to evaluate some selection processes and carry out calculations. Kumar and Chandrakar (2013) used MCDM to determine GSCM (used to reduce waste, reduce emission, preserving the quality of natural resources etc.) performance with the help of the parameter related to GSCM performance. Yazdani (2014) focused on finding the right supplier based on fuzzy MCDM process. The weights of criteria are calculated by analytical hierarchy process (AHP) (Saaty, 2008) and the final ranking was achieved by fuzzy technique for order preference by similarity to an ideal solution (TOPSIS) (Opricovic \& Tzeng, 2004). Agarwal et al. (2011) presented a review of various MCDM methodologies for solving the supplier evaluation and selection process.

\section{Methodology}

The Methodology adopted in this research is directed to rank the criteria for the selection of Dumping Area as well as to select the best dumping site among the 4 sites of Durg-Bhilai. Firstly AHP (allows the user to access the relative weight of multiple criteria against given criteria in an intuitive manner) is applied to find out the weightings of criteria and after that TOPSIS method is used which is a method of compensatory aggregation for selecting the best Dumping Area in Durg-Bhilai. At last, the result is compared with the quality function deployment (QFD) technique.

In this research, the integration of the hierarchical MCDM method with QFD has been made in such a fashion so that the integration obeys the set of QFD implementation rules suggested by Burke et al. (2012) to act as guidelines for building and scoring QFD matrices. The rules are helpful to the QFD analyst while fitting any MCDM/scoring model appropriately to the QFD matrix. It has been shown that how the outcome of the selection decision varies with a slight change in the CReqs as well as EReqs. The hierarchical QFD matrix offers a symbolic scale in order to facilitate the assignment of importance weights for each CReq and.

\subsection{Classification of criteria on the basis of expert opinion}

The different criteria are selected according to the response of the questionnaire sent to municipal officials and discussion with the decision makers and these can be divided into Customers and Engineering Requirements as below:

Customers' requirements

1. Geographic Location (GL)

2. Raining water way facilities (RW)

3. Disposal Flexibilities (DF)

4. Duration (D)

5. Auxiliaries (A) 
Engineering Requirements

1. Facility (F)

2. Technical Capabilities(TC)

The criteria for customer's requirement can further be discussed in detail as follows:

1. Geographic Location (GL) - an ideal location for dumping the solid waste should not have landfill within $200 \mathrm{~m}$ of lake or pond, river, National highway. It should be well within flood-prone area, wetland and $300 \mathrm{~m}$ from a public park

2. Raining waterway facilities (RW) - In Rainy Season, raining water comes into contact with waste in the disposal area, so there must be a way for the expulsion of raining water.

3. Disposal Flexibilities (DF) - Different types of waste should be dumped in various types of bins according to composition and waste constituents along with this there should be enough flexibility for anaerobic digestion of waste with the help of bacteria.

4. Duration (D) - It should be durable and long lasting for a span of 20-25 years or above.

5. Auxiliaries (A) - It includes availability of Weighbridge, Fencing, Gate, Transportation road etc.

\section{Result and Discussion}

The proposed methodology is applied to different processes of Municipal Solid Waste Management \& Dumping Areas of Durg-Bhilai. An attempt has been made to evaluate 4 Dumping Areas namely Kundara Para (S1), Potiyakala (S2), Jamul (S3), and Radhika Nagar (S4) having 5 criteria which are related to Customer Requirements.

\subsection{Ranking of Dumping Areas using AHP-TOPSIS}

A matrix is then prepared including values as per our understanding of the response of the questionnaire and discussion with the decision makers.

\section{Table 1}

Criteria Matrix

\begin{tabular}{lccccc}
\hline Criteria's & $\begin{array}{c}\text { Geographic } \\
\text { Location } \\
\text { (GL) }\end{array}$ & $\begin{array}{c}\text { Raining Water } \\
\text { Way Facilities } \\
\text { (RW) }\end{array}$ & $\begin{array}{c}\text { Disposal } \\
\text { Flexibilities } \\
\text { (DF) }\end{array}$ & $\begin{array}{c}\text { Durability } \\
\text { (D) }\end{array}$ & $\begin{array}{c}\text { Auxiliaries } \\
\text { (A) }\end{array}$ \\
\hline Geographic Location (GL) & 1 & 5 & 3 & 2 & 4 \\
Raining Water Way Facilities (RW) & 0.2 & 1 & 0.33 & 0.33 & 0.2 \\
Disposal Flexibilities (DF) & 0.33 & 3 & 1 & 0.25 & 5 \\
Durability (D) & 0.5 & 3 & 4 & 1 & 2 \\
Auxiliaries (A) & 0.25 & 5 & 0.2 & 2 & 1 \\
\hline
\end{tabular}

After getting the above matrix AHP technique is used to find out the weightage of each criterion and represented in the table below:

\section{Table 2}

Weightage of Criterions

\begin{tabular}{cc}
\hline Criteria's & Weightage (W) \\
\hline Geographic Location (GL) & 0.401 \\
Raining Water Way Facilities (RW) & 0.052 \\
Disposal Flexibilities (DF) & 0.161 \\
Durability (D) & 0.253 \\
Auxiliaries (A) & 0.134 \\
\hline
\end{tabular}


Table 2 clearly indicates that geographic location carries the maximum weightage among all considered for evaluation and thus it is the most important factor and area of concern for selecting a dumping yard.

$$
\mathrm{CR}=0.07 / 1.12=0.0625
$$

Now, since CR is less than 0.10 , so the values of matrix 1 , has been decided, is correct i.e. there is good consistency in the judgments made. Also, there is no contradiction in the judgments. After AHP technique TOPSIS method is applied for the evaluation of dumping areas on the basis of suggested criteria's as shown below:

\section{Table 3}

Pertinent evaluation attributes for TOPSIS

\begin{tabular}{cccccc}
\hline Dumping Area & $\begin{array}{c}\text { Geographical } \\
\text { Location }\end{array}$ & $\begin{array}{c}\text { Raining Water } \\
\text { Way Facilities }\end{array}$ & $\begin{array}{c}\text { Disposal Flexi- } \\
\text { bilities }\end{array}$ & Durability & $\begin{array}{c}\text { Basic Facili- } \\
\text { ties }\end{array}$ \\
\hline Kundara Para & 6 & 4 & 5 & 8 & 3 \\
Potiyakala & 8 & 6 & 6 & 9 & 5 \\
Jamul & 8 & 5 & 5 & 8 & 4 \\
Radhika Nagar & 4 & 6 & 4 & 7 & 3 \\
\hline
\end{tabular}

For evaluation through TOPSIS technique $\left(\sum \mathrm{x}_{\mathrm{ij}}\right)^{1 / 2}$ for each column should be calculated, after that we divide each column by $\left(\sum \mathrm{x}_{\mathrm{ij}}\right)^{1 / 2}$ to get $\mathbf{r}_{\mathrm{ij}}$. In the next step $\mathrm{v}_{\mathrm{ij}}$ is calculated by multiplying each column by $\mathrm{w}_{\mathrm{j}}$. It is then followed by determining ideal solution and negative ideal solution $\mathrm{A}^{*}$ and $\mathrm{A}^{\prime}$ respectively and their separations. Finally the relative closeness to the ideal solution $\mathrm{C}_{\mathrm{i}}{ }^{*}=\mathrm{S}_{\mathrm{i}}^{\prime} /\left(\mathrm{S}_{\mathrm{i}}{ }^{*}+\mathrm{S}_{\mathrm{i}}^{\prime}\right)$ i.e. represented below:

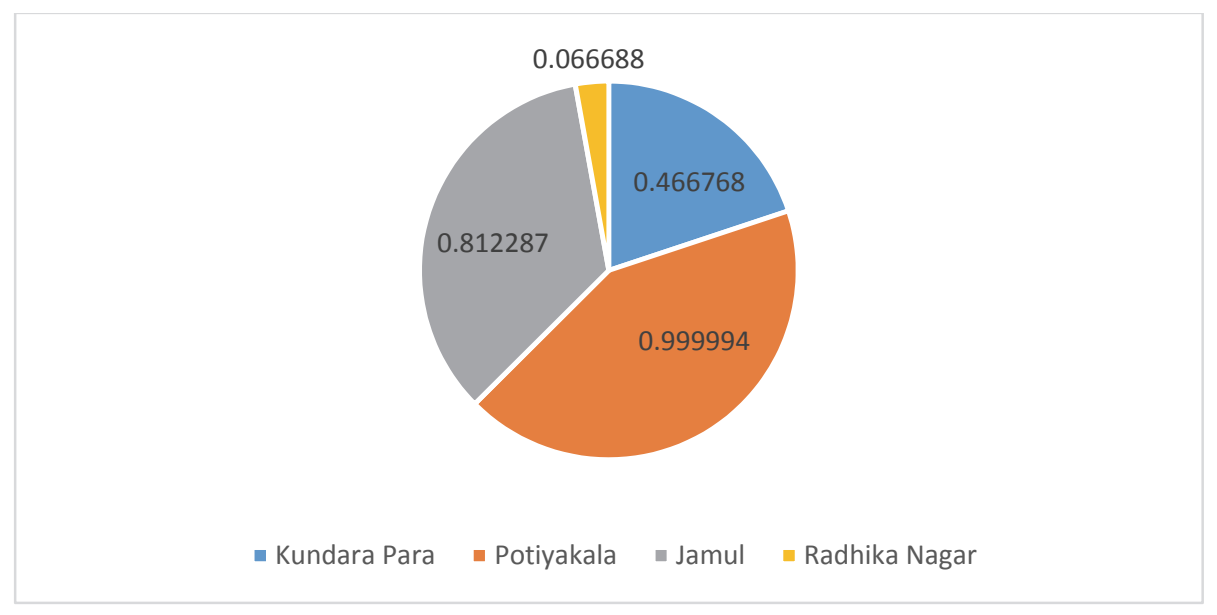

Fig. 1. Ranking of Dumping Areas

Fig. 1 shows the ranking of the four dumping areas and it clearly shows that Potiyakala is the best Dumping Area among four Dumping Areas of Durg-Bhilai.

\subsection{Formation of QFD Matrix}

The central relationship matrix for the hierarchical QFD model has been developed in Table 5. This central relationship matrix depicts the relationships among criteria for CReqs and EReqs. The relationship utilizes symbolic scale whose utility values for CReqs generated using the hierarchical model have been considered in the central relationship matrix. The matrix is generated in order to trade-off among 
the CReqs and EReqs. At this juncture, the following equations are utilized to compute the degree of importance $\left(w_{j}\right)$ and normalized degree of importance $\left(w_{j}\right)$ for the EReqs.

$$
\begin{aligned}
& w_{j}=\sum_{i=1}^{m}\left(R_{i j} * c_{i}\right) \\
& \overline{w_{J}}=\frac{w_{j} \times 100}{\sum_{j=1}^{n} w_{j}}
\end{aligned}
$$

\section{Table 5}

The QFD matrix for supplier selection

\begin{tabular}{lccc}
\hline & \multicolumn{2}{c}{ Engineering Requirement } & Importance weights for Cus- \\
Eustomer Requirements CReqs & F & TC & tomer Requirements \\
\hline Geographic Location (GL) & 5 & 9 & 0.401 \\
Raining Water Way Facilities (RW) & 5 & 9 & 0.052 \\
Disposal Flexibilities (DF) & 1 & 5 & 0.161 \\
Duration(D) & 1 & 9 & 0.253 \\
Auxiliaries (A) & 5 & 7.581 & 0.134 \\
\hline $\begin{array}{l}\text { Degree of importance for selection } \\
\left.\text { criteria( } \mathrm{w}_{\mathrm{j}}\right)\end{array}$ & 3.349 & 69.360 & \\
$\begin{array}{l}\text { Normalized degree of importance } \\
\text { for selection criteria }\left(\mathrm{w}_{\mathrm{j}}\right)\end{array}$ & 30.640 & & \\
\hline
\end{tabular}

\section{Table 6}

Scores of the hierarchical QFD model

\begin{tabular}{cccccc}
\hline EReqs & Weights & Kundara Para & Potiyakala & Jamul & Radhika Nagar \\
& & & & & 0.276 \\
\hline Facility & 30.64 & 0.176 & 0.464 & 0.174 & 0.129 \\
\hline TC & 69.36 & 0.138 & 0.55 & 085 \\
\hline Scores & & 14.96432 & 52.36496 & 20.52528 & 11.55184 \\
\hline
\end{tabular}

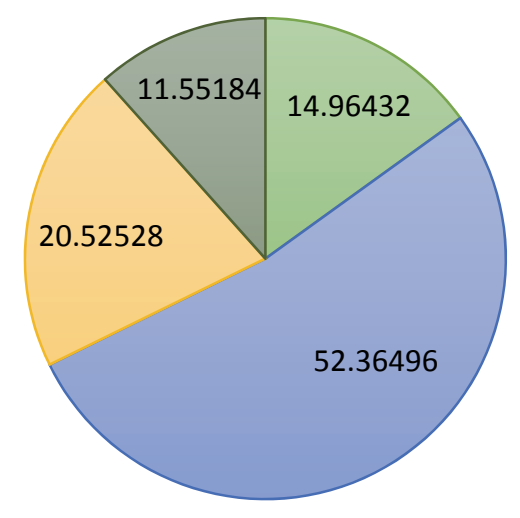

$\square$ Kundara Para $\square$ Potiyakala $\square$ Jamul $\square$ Radhika Nagar

Fig. 2. Scores of the hierarchical QFD model 
The representation of the relative comparison among the Dumping Areas on the combined AHP-QFD model is $\mathrm{S} 2>\mathrm{S} 3>\mathrm{S} 1>\mathrm{S} 4$

\section{Conclusion}

According to the survey and analysis carried, the selection for appropriate dumping ground has been evaluated according to 5 criteria's i.e. Geographic Location, Raining waterway facilities, Disposal, Flexibilities \& Durability Auxiliaries and other sub criteria's which were gathered with the help of municipal officials in Nagar Nigam Durg. AHP technique has been used to find the weightages of different criteria's and the results came for each criterion as $0.401,0.052,0.161,0.253 \& 0.134$ respectively. In addition, TOPSIS method has been used and the scores calculated were 0.999994311, $0.812286,0.46676$ \& 0.0666 for Potiyakala, Jamul, Kundara Para \& Radhika Nagar, respectively. After that through QFD model relative comparison among dumping areas were established as 52.36, 20.52, 14.96 \& 11.55 for Potiyakala, Jamul, Kundara Para \& Radhika Nagar, respectively and after comparing the results came from TOPSIS \& QFD authors came to the conclusion that Potiyakala is the best dumping yard among all considered in Durg-Bhilai area.

\section{References}

Agarwal, D., \& Gupta, A. K. (2011). Hazardous Waste Management: Analysis of Indian Scenario and Perspective Governance. VSRD Technical \& Non-Technical Journal, 2(9), 484-495.

Agarwal, P., Sahai, M., Mishra, V., Bag, M., \& Singh, V. (2011). A review of multi-criteria decision making techniques for supplier evaluation and selection. International Journal of Industrial Engineering computations, 2(4), 801-810.

Agarwal, A., Singhmar, A., Kulshrestha, M., \& Mittal, A. K. (2005). Municipal solid waste recycling and associated markets in Delhi, India. Resources, Conservation and Recycling, 44(1), 73-90.

Bundela, P. S., Gautam, S. P., Pandey, A. K., Awasthi, M. K., \& Sarsaiya, S. (2010). Municipal solid waste management in Indian cities-A review. International Journal of Environmental Sciences, 1(4), 591.

Burke, E., Kloeber Jr, J. M., \& Deckro, R. F. (2002). Using and abusing QFD scores. Quality Engineering, 15(1), 9-21.

Chandraker, R., \& Kumar, R. (2013). Evaluation and measurement of performance of GSCM in Chhattisgarh manufacturing industries (INDIA). International Journal of Application or Innovation in Engineering \& Management, 2(6), 240-249.

Guria, N., \& Tiwari, V. K. (2010). Municipal solid waste management in Bilaspur city (CG) India. National Geographer, Allahabad, 1, 1-16.

Joshi, R., \& Ahmed, S. (2016). Status and challenges of municipal solid waste management in India: A review. Cogent Environmental Science, 2(1), 1139434.

Kaushal, R. K., Varghese, G. K., \& Chabukdhara, M. (2012). Municipal solid waste management in India-current state and future challenges: a review. International Journal of Engineering Science and Technology, 4(4), 1473-1489.

Lanjewar, S. S., Sharma, K., \& Mahishwar, A. (2014). Solid waste management need \& implementation in Raipur, Chhattisgarh. Recent Research in Science and Technology, 6(1), 60-61

Muttamara, S., Sales, C. L., \& Phunsiri, S. (1996). Solid waste recycling, disposal and management in Bangkok. Journal of Solid Waste Technology and Management, 23(4), 226-237.

Opricovic, S., \& Tzeng, G. H. (2004). Compromise solution by MCDM methods: A comparative analysis of VIKOR and TOPSIS. European journal of operational research, 156(2), 445-455.

Rajput, R., Prasad, G., \& Chopra, A. K. (2009). Scenario of solid waste management in present Indian context. Caspian Journal of Environmental Sciences, 7(1), 45-53.

Saaty, T. L. (2008). Decision making with the analytic hierarchy process. International journal of services sciences, 1(1), 83-98. 
Sahu, A. K. (2007, September). Present scenario of municipal solid waste (MSW) dumping grounds in India. In Proceedings of the international conference on sustainable solid waste management (pp. 5-7).

Sharholy, M., Ahmad, K., Mahmood, G., \& Trivedi, R. C. (2008). Municipal solid waste management in Indian cities-A review. Waste management, 28(2), 459-467.

Siddiqui, J., Pandey, G., \& Akhtar, S. (2013). A case study of solid waste management in Mysore City. International Journal of Application or Innovation in Engineering and Management, 2(11), 15.

Yazdani, M. (2014). An integrated MCDM approach to green supplier selection. International Journal of Industrial Engineering Computations, 5(3), 443-458.

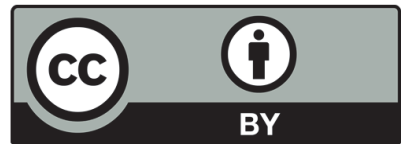

(C) 2018 by the authors; licensee Growing Science, Canada. This is an open access article distributed under the terms and conditions of the Creative Commons Attribution (CC-BY) license (http://creativecommons.org/licenses/by/4.0/). 